OAK RIDGE

NATIONAL

LABORATORY
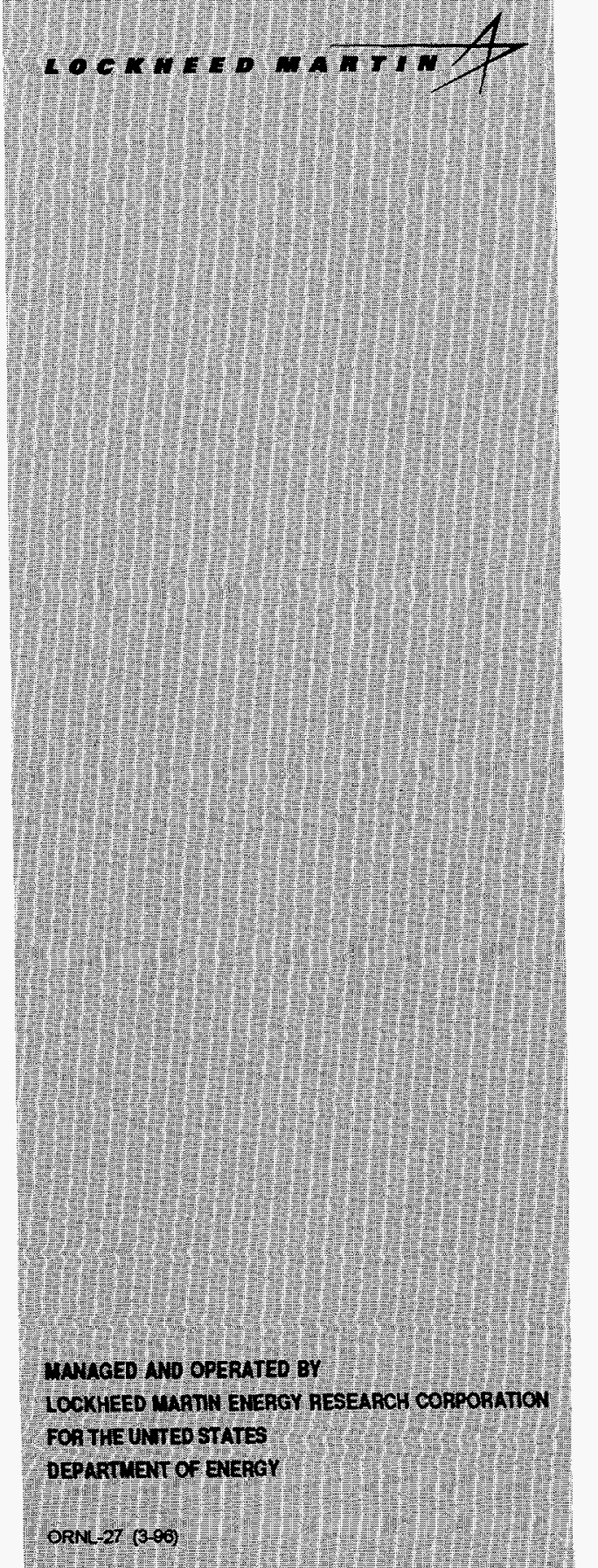

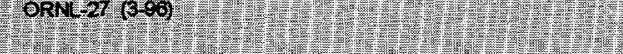

\section{Results of the Independent Radiological Verification Survey at 112 Avenue E, Lodi, New Jersey (LJ082V)}

R. E. Rodriguez

C. A. Johnson

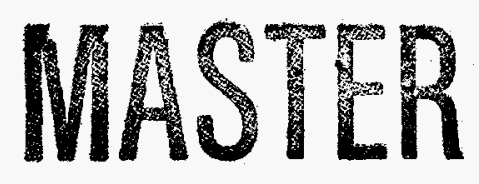

WWTWUTON OF THIS DOCUMENT IS UNLIMITED

$4 m$ 
This report has been reproduced directly from the best available copy.

Available to DOE and DOE contractors from the Office of Scientific and Technical Information, P. O. Box 62, Oak Ridge, TN 37831; prices available from (423) 576-8401, FTS 626-8401.

Available to the public from the National Technical Information Service, U.S. Department of Commerce, 5285 Port Royal Road, Springfield, VA 22161.

This report was prepared as an account of work sponsored by an agency of the United States Government. Neither the United States Government nor any agency thereof, nor any of their employees, makes any warranty, express or implied, or assumes any legal liability or responsibility for the accuracy, completeness, or usefulness of any information, apparatus, product, or process disclosed, or represents that its use would not infringe privately owned rights. Reference herein to any specific commercial product, process, or service by trade name. trademark, manufacturer, or otherwise, does not necessarily constitute or imply its endorsement, recommendation, or favoring by the United States Government or any agency thereof. The views and opinions of authors expressed herein do not necessarily state or reflect those of the United States Government of any agency thereof. 
HEALTH SCIENCES RESEARCH DIVISION

Environmental Restoration and Waste Management Non-Defense Programs

(Activity No. EX 202001 0; ADS1310AA)

\title{
Results of the Independent Radiological Verification Survey at 112 Avenue E, Lodi, New Jersey (LJ082V)
}

\author{
R. E. Rodriguez and C. A. Johnson
}

Date issued - September 1996

Investigation Team

R. D. Foley-Measurement Applications and Development Manager

M. E. Murray-FUSRAP Project Director

R. E. Rodriguez-Survey Team Leader

Survey Team Members

R. C. Gosslee S. P. McKenzie

R. E. Rodriguez

Work performed by the

Measurement Applications and Development Group

Prepared by the

OAK RIDGE NATIONAL LABORATORY

Oak Ridge, Tennessee 37831-6285

managed by

LOCKHEED MARTIN ENERGY RESEARCH CORP.

for the

U. S. DEPARTMENT OF ENERGY

under contract DE-AC05-960R22464 


\section{DISCLAIMER}

Portions of this document may be illegible in electronic image products. Images are produced from the best available original document. 


\section{CONTENTS}

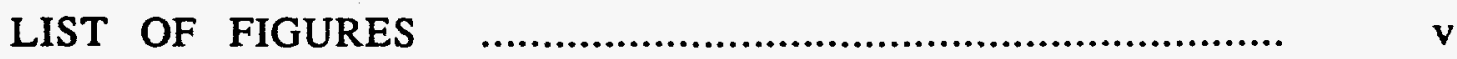

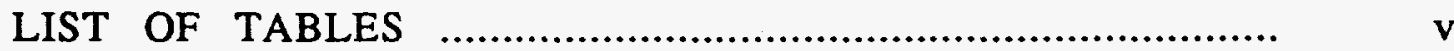

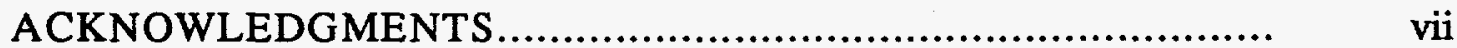

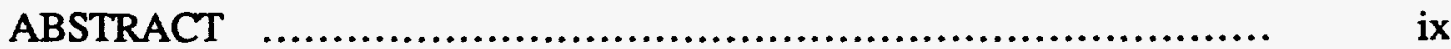

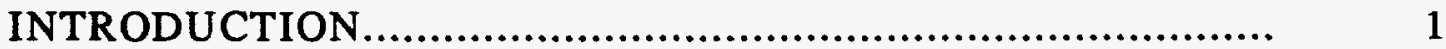

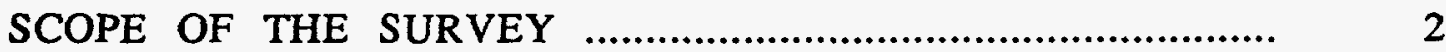

VERIFICATION SURVEY AND ANALYSIS................................ 3

CONCLUSIONS $\quad$...................................................... 4

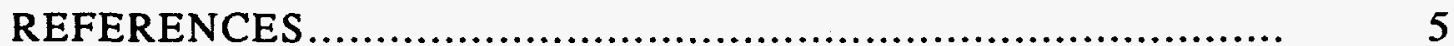




\section{LIST OF FIGURES}

1 Diagram showing the general location of vicinity properties in Lodi, New Jersey relative to the Maywood Interim Storage Site (MISS)

2 Diagram showing gamma measurements and soil sampling locations at 112 Ave. E, Lodi, New Jersey

\section{LIST OF TABLES}

1 Applicable guidelines for protection against radiation

2 Background radiation levels and concentrations of selected radionuclides in soil in the northern New Jersey area.........................................

3 Concentrations of radionuclides in soil at 112 Avenue E., Lodi, New Jersey. 



\section{ACKNOWLEDGMENTS}

This project was sponsored by the Office of Environmental Restoration, U. S. Department of Energy, under contract DE-AC05-84OR21400 with Lockheed Martin Energy Systems, Inc. The authors wish to acknowledge the contributions of D. A. Roberts and D. A. Rose of the Measurement Applications and Development Group for participation in the sample preparation and analyses and reporting of data for this survey, and of M. S. Uziel for the graphics in this report. The surveying assistance of R. C. Gosslee and S. P. McKenzie is also gratefully acknowledged. 



\begin{abstract}
Thorium ores were processed by the Maywood Chemical Works until the property was sold to Stepan Chemical Company in 1959. Wastes were stored at what is now called the Maywood Interim Storage Site (MISS), owned by the U. S. Department of Energy (DOE). Because of the migration of residuals off site into the surrounding areas, the Stepan property and several vicinity properties were designated for remedial action under the 1984 Energy and Water Development Appropriations Act.

The DOE conducted radiological surveys of these sites to evaluate current radiological conditions as part of the Formerly Utilized Sites Remedial Action Program (FUSRAP). In 1988, radiological surveys of some private residential properties on Avenue $E$ in Lodi, New Jersey were conducted by members of an ORNL radiological survey team. Results of this survey indicated radiological contamination in excess of the DOE criteria for surface contamination at this vicinity property (112 Avenue E), and it was recommended for remediation.

In the fall of 1995, a verification survey of this vicinity property was conducted by ORNL, the independent verification contractor for this effort, in conjunction with decontamination operations conducted under the supervision of Bechtel National Incorporated. The verification survey included complete surface gamma scans of the grounds and the collection of soil samples for radionuclide analysis. This report describes the radiological verification survey of this residential property.

Based on the remedial action and verification survey data reported in this document, all radiological measurements fall below the limits prescribed by DOE radiological guidelines established for this site, and the property at 112 Avenue $E$, Lodi, New Jersey successfully meets the DOE radiological guidelines for unrestricted use.
\end{abstract}




\section{Results of the Independent Radiological Verification Survey \\ at 112 Avenue E, Lodi, New Jersey (LJ082 V)*}

\section{INTRODUCTION}

Thorium ores were processed by the Maywood Chemical Works (MCW)1, Maywood, New Jersey, between 1916 and 1959. The MCW ceased thorium processing in 1959 and the 30-acre property was sold that same year to Stepan Chemical Company. During the early years of operation, MCW stored wastes and residues in low-lying areas west of the processing facilities, now called the Maywood Interim Storage Site (MISS). Subsequently, residuals containing radioactive materials migrated off-site to the surrounding area, and the Stepan property and several vicinity properties at this and other sites were designated by Congress for remedial action as a result of the 1984 Energy and Water Development Appropriations Act.

The waste produced by the thorium extraction process was a sand-like material containing residual amounts of thorium and its decay products, with smaller quantities of uranium and its decay products. Because some of the wastes had been carried downstream by Lodi Brook, and some area residents had also used the sand-like wastes as mulch in their yards, the properties in the vicinity of the MCW were included as a decontamination research and development project under the Department of Energy (DOE) Formerly Utilized Sites Remedial Action Program (FUSRAP).

The location of Lodi, New Jersey, relative to the Stepan property and the DOEowned Maywood Interim Storage Site is shown in Fig. 1.

At the request of the DOE, the Measurement Applications and Development (MAD) Group from Oak Ridge National Laboratory (ORNL) conducted investigative radiological surveys of properties surrounding the former processing plant. In May 1988, a radiological survey was conducted on the private, residential property at 112 Avenue E., Lodi, New Jersey by members of the MAD Group of ORNL. 2

The survey consisted of a complete gamma scan of the entire property outdoors and the collection of systematic and biased soil samples. The survey report, published in 1989, concluded that areas of elevated gamma were scattered about the front, back, and side yards, and soil analysis from these areas indicated that the property contained residual radioactive material primarily from the $232 \mathrm{Th}$ decay chain. 2 Additionally, both the concentration and extent of $232 \mathrm{Th}$ found on the property were in excess of the applicable DOE criteria, and the property was scheduled for remedial action.

*The survey was performed by members of the Measurement Applications and Development Group of the Health Sciences Research Division of Oak Ridge National Laboratory under DOE contract DE-AC0584 OR21400. 
Decontamination of the facility to current guidelines was conducted by subcontractor personnel in conjunction with the verification survey in the fall of 1995 under the direction of Bechtel National Incorporated (BNI), the project management contractor for FUSRAP. Thermo NUtech was the radiological support subcontractor.

The independent radiological verification survey detailed in this report was performed in March and November 1995 under the FUSRAP program by members of the Measurement Applications and Development Group at ORNL, the independent verification contractor for this property. The DOE's policy to assign an independent verification contractor ensures the effectiveness of remedial actions performed within FUSRAP and confirms the site's compliance with DOE guidelines.

This report describes the radiological verification survey of the private, residential property at 112 Avenue E, Lodi, New Jersey, conducted by ORNL at the request of the DOE's Office of Environmental Restoration. The property, a single family dwelling with concrete walks and asphalt driveway, was marked in $25-\mathrm{ft}$ grids for the survey. A diagram of the property is shown in Fig. 2.

\section{SCOPE OF THE SURVEY}

\section{Objectives}

The objective of the verification activities was to confirm (1) that available documentation adequately and accurately describes the post-remedial action of the facility that is to be verified, and (2) that the remedial action reduced contamination levels to within authorized limits. Applicable DOE residual radioactivity guidelines for protection of the general public are summarized in Table 1. Typical background radiation levels for the New Jersey area are presented in Table 2.

\section{Survey Methods}

A comprehensive description of the survey methods and instrumentation used in this survey is given in Procedures Manual for the ORNL Radiological Survey Activities (RASA) Program, ORNL/TM-8600 (April 1987), and Measurement Applications and Development Group Guidelines, ORNL-6782 (January 1995).3,4

The radiological verification survey of this property included: (1) a complete surface gamma scan of the grounds and (2) the collection of surface and subsurface soil samples for analysis.

Gamma radiation levels were determined using a portable sodium iodide (NaI) gamma scintillation detector connected to a Victoreen ratemeter. Measurements were recorded in counts per minute (cpm) and converted to microroentgens per hour $(\mu \mathrm{R} / \mathrm{h})$.

Confirmatory surface $(0-15 \mathrm{~cm}$, or 0 to $6 \mathrm{in})$ and subsurface $(15-30 \mathrm{~cm}$, or 6 to 12 in) soil samples were collected from under the basement floor and at various locations over the property. Samples taken where elevated gamma levels were found are referred to as biased samples and are labeled VB1 through VB6. Systematic samples (VS1 to VS9) 
were taken from locations irrespective of gamma levels. Two samples (VS1 and VS2) were taken from under the concrete floor in the basement, and two (VB6 and VS9) were taken from under the concrete sidewalk along the east side of the house. Locations of the samples are shown in Fig. 2, and results of the radionuclide analysis are shown in Table 3.

Tables 1 and 2, summarizing current guidelines for sites included within FUSRAP and typical background radiation levels for the New Jersey area, provide comparison with the survey results presented in this section. Gamma measurements presented in this report are gross readings; background radiation levels have not been subtracted. Similarly, background concentrations have not been subtracted from radionuclide concentrations in soil.

\section{VERIFICATION SURVEY AND ANALYSIS}

Applicable DOE guidelines and typical background radiation levels for the northern New Jersey area are presented in Tables 1 and 2. These data are provided for comparison with the survey results presented in this section. All measurements presented in this report are gross readings; background radiation levels have not been subtracted. Similarly, background concentrations have not been subtracted from radionuclide concentrations in soil samples.

\section{Gamma Exposure Rates}

Gamma measurements generally ranged from $7-18 \mu \mathrm{R} / \mathrm{h}$ at the surface over the property, and up to $25 \mu \mathrm{R} / \mathrm{h}$ on the east corner of the house. Two soil samples were taken from this area. These measurements are comparable to the natural background levels for this area. Elevated gamma levels ranging from 12 to $80 \mu \mathrm{R} / \mathrm{h}$ were measured in a small area around the tree in the backyard, indicating spotty contamination. Two biased samples and four systematic soil samples were taken close to and around the tree in the backyard.

\section{Soil Samples}

Surface and subsurface soil samples were collected indoors from underneath the basement floor and from outside in the front, side, and back yards. Biased samples were taken from excavated areas (before backfilling) and from areas of elevated gamma. Although gamma levels were elevated around the tree in the southern end of the back yard, the owner did not want the tree removed, so extensive soil sampling was done around the tree. Six soil samples were taken in close proximity to each other and to the tree. All samples were analyzed for radium (226Ra), thorium (232Th), and uranium (238U).

Results of the soil analyses are in picocuries per gram $(\mathrm{pCi} / \mathrm{g})$ and are shown in Table 3. Radionuclide concentrations of $226 \mathrm{Ra}$ and $232 \mathrm{Th}$ in systematic samples ranged from 0.49 to $1.0 \mathrm{pCi} / \mathrm{g}$ and 0.72 to $2.5 \mathrm{pCi} / \mathrm{g}$, respectively. Concentrations of $226 \mathrm{Ra}$ and 232Th in biased samples ranged from 0.96 to 2.3 and from 2.3 to $20 \mathrm{pCi} / \mathrm{g}$, respectively. The DOE guideline for these radionuclides in soil is $5 \mathrm{pCi} / \mathrm{g}$ above background averaged over $100 \mathrm{~m}^{2}$ for surface and subsurface soil in this area. 5

The maximum of 20 and $11 \mathrm{pCi} / \mathrm{g} 232 \mathrm{Th}$ (VB4 and VB5, Table 3) were found in close proximity to each other in a small area as shown on Fig. 2. The area was no more 
than $5 \mathrm{~m}^{2}$ as delineated by sampling and gamma radiation measurements. The resulting average of $14.5 \mathrm{pCi} / \mathrm{g}$ (when background is subtracted) falls below the DOE "hot spot" criteria for this size area (Table 1). All other values are well below the DOE guidelines.

Concentrations of $238 \mathrm{U}$ in soil ranged from 0.56 to $2.3 \mathrm{pCi} / \mathrm{g}$ in systematic samples, and from 1.1 to $10 \mathrm{pCi} / \mathrm{g}$ in biased samples. These values are well below the site specific guidelines of $100 \mathrm{pCi} / \mathrm{g}$ for total uranium ( $50 \mathrm{pCi} / \mathrm{g}$ for $238 \mathrm{U}$ ) averaged over $100 \mathrm{~m}^{2}$ for uranium in soil (Table 1). 6

\section{CONCLUSIONS}

Prior to remedial efforts, thorium residuals exceeding guidelines were found in scattered small areas outdoors on the property at 112 Avenue E, Lodi, New Jersey. Decontamination of these areas was performed by subcontractors under the direction of BNI.

The remediated areas on the grounds of the property, including the area around the tree in the back yard were thoroughly investigated for radionuclide residues. The results of soil radionuclide analysis for ${ }^{238 \mathrm{U}}, 226 \mathrm{Ra}$, and $232 \mathrm{Th}$ (Table 3 ) indicate that all soil concentration measurements are within the limits prescribed by DOE radiological guidelines. Gamma exposure rates were all below guideline levels and comparable to the average background values for the area.

Results of the independent radiological verification survey of this property by ORNL confirm that residual radionuclide contaminations have been remediated to levels below DOE guidelines for FUSRAP sites.

Based on the results of the post remedial action data (Post-Remedial Action Report for the Maywood Site Vicinity Properties at 79 Avenue B, 90 Avenue $C, 108$ Avenue $E$, 112 Avenue E, and 113 Avenue E, Maywood, New Jersey, DOE/OR/21949-405, Bechtel National, Inc., September 1996) and confirmed by the verification survey data, all radiological measurements fall below the limits prescribed by DOE radiological guidelines established for this site, and the property at 112 Avenue E successfully meets the DOE remedial action objectives. 


\section{REFERENCES}

1. L. W. Cole, J. Berger, P. Cotten, R. Gosslee, L. Sowell, and C. Weaver, Radiological Assessment of Ballod Associates Property (Stepan Chemical Company), Maywood, New Jersey, Oak Ridge Associated Universities, Oak Ridge, Tenn., July 30, 1981.

2. R. D. Foley, L. M. Floyd, Results of the Radiological Survey at 112 Avenue E., Lodi, New Jersey (LJ082), ORNL/RASA-88/70, Martin Marietta Energy Systems, Inc., Oak Ridge Natl. Lab., June 1989.

3. T. E. Myrick, B. A. Berven, W. D. Cottrell, W. A. Goldsmith, and F. F. Haywood, Procedures Manual for the ORNL Radiological Survey Activities (RASA) Program, ORNL/TM-8600, Martin Marietta Energy Systems, Inc., Oak Ridge Natl. Lab., April 1987.

4. Oak Ridge National Laboratory, Health Sciences Research Division, Measurement Applications and Development Group Guidelines, ORNL-6782, Martin Marietta Energy Systems, Inc., January 1995.

5. Memo, W. J. Muszynski, P.E., Acting Regional Administrator, U.S. EPA, Region II, New York, NY, March 25, 1994; and Correspondence, J. La Grone, Manager, Oak Ridge Operations, U.S. DOE, April 13, 1994.

6. Memo, J. W. Wagoner II, Director, Division of Off-Site Programs, Office of Eastern Area Programs, Office of Environmental Restoration, U.S. DOE, to L.K. Price, Director, Former Sites Restoration Division, Oak Ridge Field Office, U.S. DOE, April 25, 1994. 


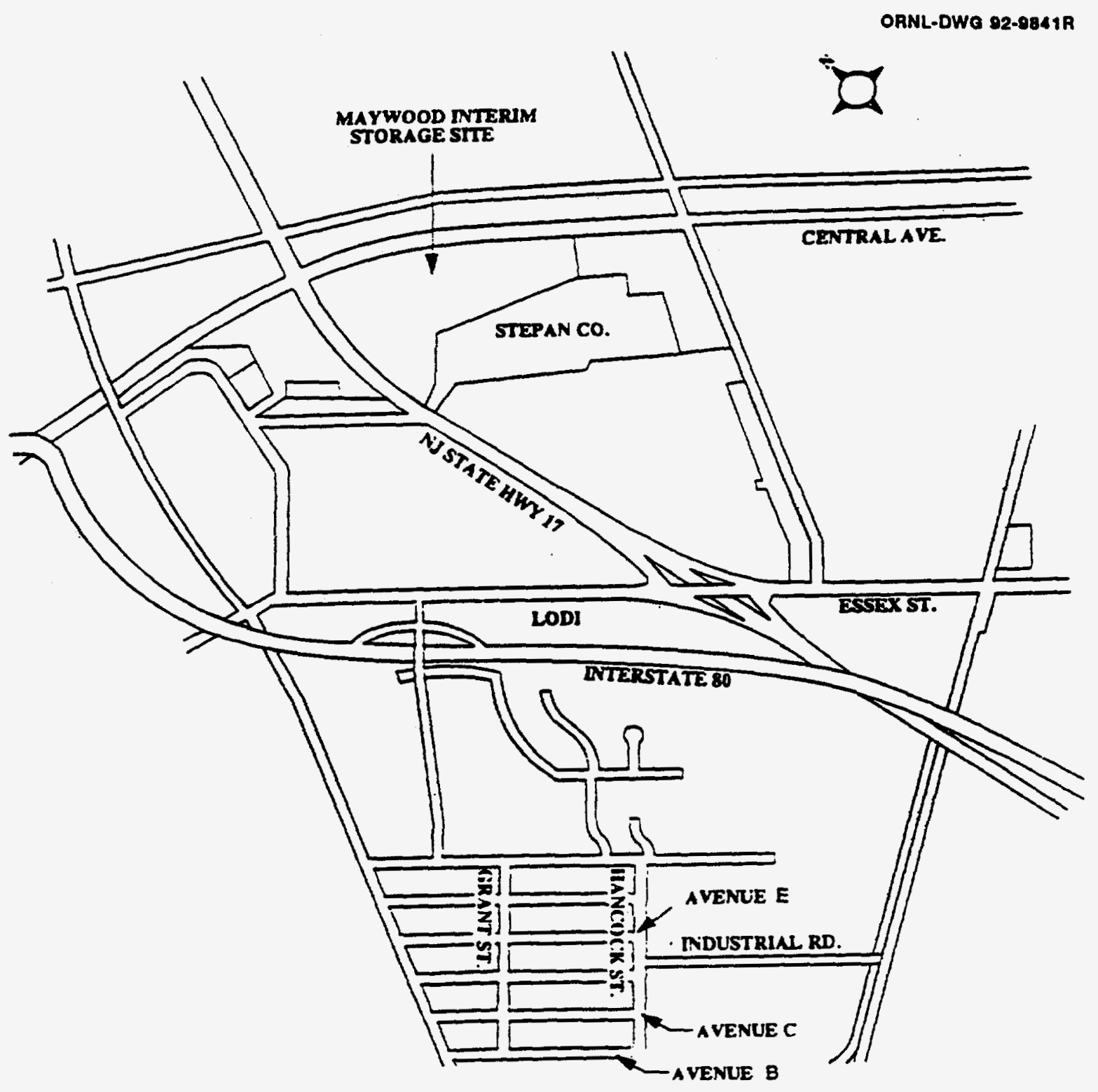

Fig. 1. Diagram showing the general location of vicinity properties in Lodi, New Jersey relative to the Maywood Interim Storage Site (MISS). 


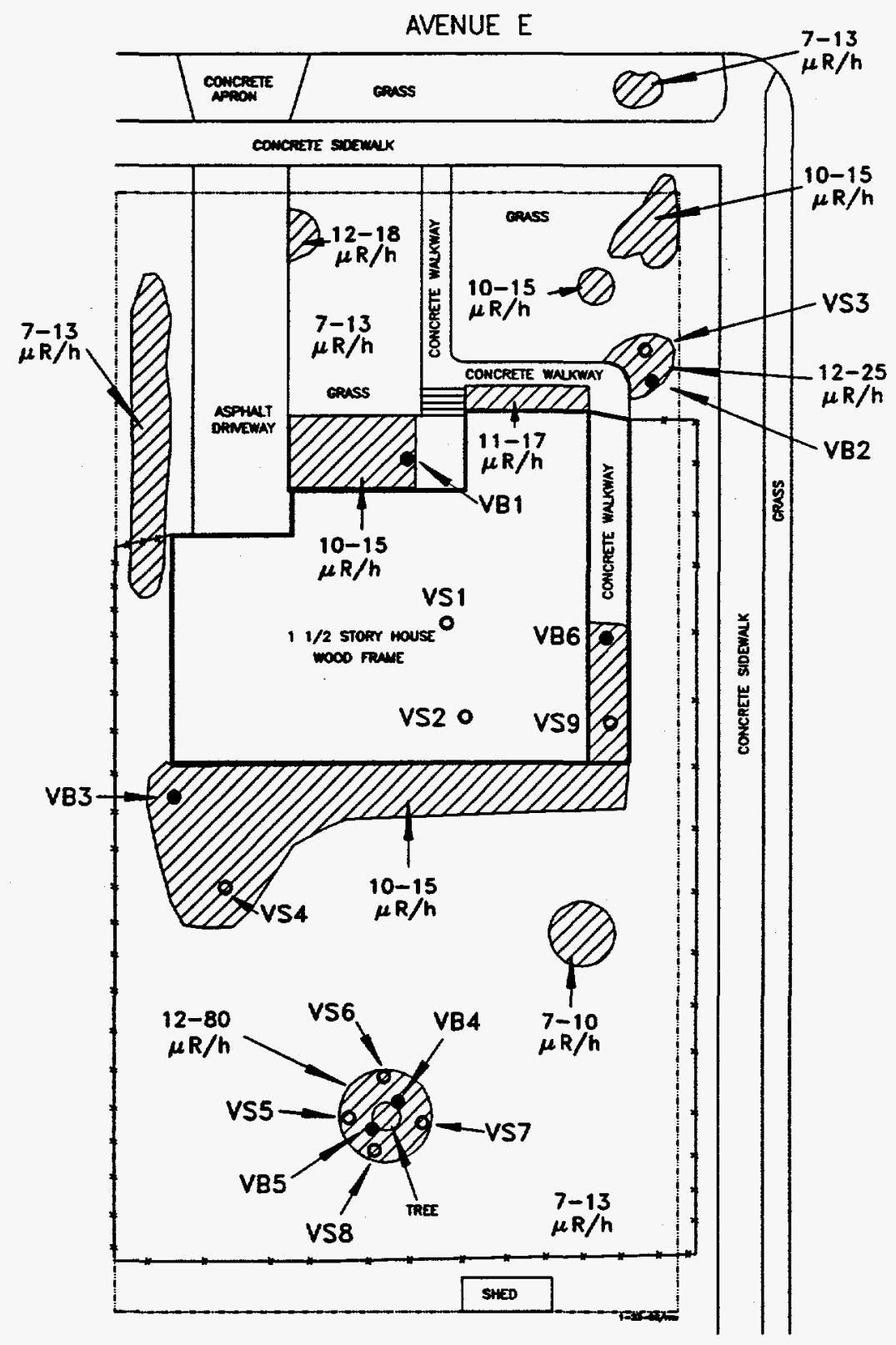

ORNL-DWG $96-3370$
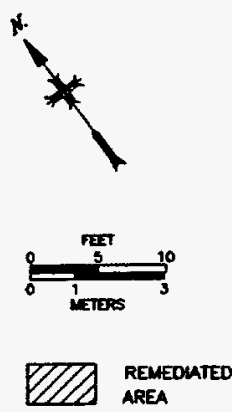

- PROPERTY

\# FENCE

- BIASED soll sAMPLES

- STSTEMTIC SOL SAMPLES

LJ082V

112 AVENUE E

LODI, NEW JERSEY

Fig. 2. Diagram showing gamma measurements and soil sampling locations at 112 Ave. E, Lodi, New Jersey. 
Table 1. Applicable guidelines for protection against radiation (Limits for uncontrolled areas)

Mode of exposure
Gamma radiation
$\begin{aligned} & \text { Radionuclide con- } \\ & \text { centrations in soil } \\ & \text { (generic) }\end{aligned}$

Derived concentrations

Guideline for nonhomogeneous contamination (used in addition to the $100-\mathrm{m}^{2}$ guideline) ${ }^{e}$
Exposure conditions

Indoor gamma radiation level (above background)

Maximum permissible concentration of the following radionuclides in soil above background levels, averaged over a $100-\mathrm{m}^{2}$ area

$$
\begin{aligned}
& 226 \mathrm{Ra} \\
& 232 \mathrm{Th} \\
& \text { 230 } \mathrm{Th}
\end{aligned}
$$

Total uranium

Applicable to locations with an area $\leq 25 \mathrm{~m}^{2}$, with significantly elevated concentrations of radionuclides ("hot spots")
Guideline value

$20 \mu \mathrm{R} / \mathrm{h}^{a}$

$5 \mathrm{pCi} / \mathrm{g}$ averaged over the first $15 \mathrm{~cm}$ of soil below the surface; 15 $\mathrm{pCi} / \mathrm{g}$ when averaged over $15-\mathrm{cm}$-thick soil layers over $15 \mathrm{~cm}$ below the surface $b, c$
$G_{A}=G_{i}(100 / A)^{1 / 2}$, where
$G_{A}=$ guideline for "hot spot" of area $(A)$
$G_{i}=$ guideline averaged over a $100-\mathrm{m}^{2}$ area

aThe $20 \mu \mathrm{R} / \mathrm{h}$ shall comply with the basic dose limit (100 mrem/yr) when an appropriate-use scenario is considered.

${ }^{b}$ For residential properties in the Lodi, New Jersey, area, the guideline for ${ }^{232} \mathrm{Th}$ is $5 \mathrm{pCi} / \mathrm{g}$ for both surface and subsurface soil. 5

cThe concentration of any single radionuclide above normal background levels shall not exceed the concentration guidelines. If more than one radionuclide is present, the sum of the ratios of the measured soil concentrations of each radionuclide to its corresponding guideline shall not exceed unity.

$d$ DOE guidelines for uranium are derived on a site-specific basis. Guidelines of $100 \mathrm{pCi} / \mathrm{g}$ have been applied at this FUSRAP site. Source: Memo, J. W. Wagoner II, U.S. DOE, Uranium Guideline for the Maywood, New Jersey Site, to L. K. Price, Oak Ridge Field Office, U.S. DOE, April 1994.6

$D O E$ guidelines specify that every reasonable effort shall be made to identify and to remove any source that has a concentration exceeding 30 times the guideline value, irrespective of area. Adapted from Revised Guidelines for Residual Radioactive Material at FUSRAP and Remote SFMP Sites, April 1987.

Sources: Adapted from U.S. Department of Energy, Radiation Protection of the Public and the Environment, DOE Order 5400.5, April 1990, and U.S. Department of Energy, Guidelines for Residual Radioactive Material at Formerly Utilized Sites Remedial Action Program and Remote Surplus Facilities Management Program Sites, Rev. 2, March 1987; and U. S. Department of Energy Radiological Control Manual, DOE N 5480.6 (DOE/EH-256T), June 1992. 
Table 2. Background radiation levels and concentrations of selected radionuclides in soil in the northern New Jersey area

\begin{tabular}{lll}
\hline \multirow{2}{*}{\begin{tabular}{l} 
Type of radiation measurement $\begin{array}{c}\text { Radiation level or radionuclide } \\
\text { concentration }\end{array}$ \\
\cline { 2 - 3 }
\end{tabular}} & $\begin{array}{c}\text { Range } \\
\text { Average }\end{array}$ \\
\hline $\begin{array}{l}\text { Gamma exposure rate at } 1 \mathrm{~m} \\
\text { above ground surface }(\mu \mathrm{R} / \mathrm{h})\end{array}$ & $3-13^{a}$ & $8 b$ \\
& & \\
$\begin{array}{l}\text { Concentration of radionuclides } \\
\text { in soil (pCi/g)c }\end{array}$ & & \\
226Ra & $0.55-1.4$ & 1.0 \\
232Th & $0.53-1.5$ & 1.0 \\
$238 \mathrm{U}$ & $0.46-1.4$ & 1.0 \\
\hline
\end{tabular}

$a$ Values obtained from 14 locations in the northem New Jersey, area. Source: T. E. Myrick, B. A. Berven, and F. F. Haywood, State Background Radiation Levels: Results of Measurements Taken During 1975-1979, ORNL/TM7343, Martin Marietta Energy Systems, Inc., Oak Ridge Natl. Lab., November 1981.

$b \mathrm{U}$. S. Department of Energy, Radiological Survey of the Middlesex Municipal Landfill, Middlesex, New Jersey, DOE/EV-0005/20, April 1980.

$c$ Values obtained from 15 Locations in the northern New Jersey area. Source: T. E. Myrick, B. A. Berven, and F. F. Haywood, State Background Radiation Levels: Results of Measurements Taken During 1975-1979, ORNL/TM7343, Martin Marietta Energy Systems, Inc., Oak Ridge Natl. Lab., November 1981. 
Table 3. Concentrations of radionuclides in soil at 112 Avenue E, Lodi, New Jersey (LJ082V)

\begin{tabular}{|c|c|c|c|c|}
\hline \multirow{2}{*}{$\begin{array}{l}\text { Sample } \\
\text { numbera }\end{array}$} & \multirow{2}{*}{$\begin{array}{l}\text { Depth } \\
\text { (cm) }\end{array}$} & \multicolumn{3}{|c|}{ Radionuclide concentration ( $\mathrm{pCi} / \mathrm{g}) b$} \\
\hline & & $226 \mathrm{Ra}$ & ${ }^{232} \mathrm{Th}$ & $238 \mathrm{U}$ \\
\hline \multicolumn{5}{|c|}{ Systematic soil samplesc } \\
\hline VS1d & $61-76$ & $0.49 \pm 0.05$ & $0.73 \pm 0.09$ & $1.1 \pm 0.6$ \\
\hline VS2Ae & $0-15$ & $1.0 \pm 0.08$ & $1.2 \pm 0.1$ & $1.4 \pm 1.0$ \\
\hline VS2B & $30-45$ & $0.82 \pm 0.06$ & $0.98 \pm 0.1$ & $0.56 \pm 0.4$ \\
\hline VS2C & $76-91$ & $0.53 \pm 0.08$ & $0.72 \pm 0.09$ & $1.6 \pm 0.6$ \\
\hline VS3 & $0-15$ & $0.94 \pm 0.1$ & $2.5 \pm 0.2$ & $2.3 \pm 0.5$ \\
\hline vS4 & $0-15$ & $0.67 \pm 0.04$ & $0.80 \pm 0.05$ & $0.84 \pm 0.3$ \\
\hline VS5 & 0.15 & $0.65 \pm 0.09$ & $1.1 \pm 0.1$ & $0.66 \pm 0.3$ \\
\hline vS6 & $0-15$ & $0.59 \pm 0.09$ & $2.2 \pm 0.2$ & $1.6 \pm 0.4$ \\
\hline VS7 & $0-15$ & $0.72 \pm 0.1$ & $1.7 \pm 0.1$ & $1.3 \pm 0.4$ \\
\hline VS8 & $0-15$ & $0.69 \pm 0.1$ & $1.3 \pm 0.1$ & $1.2 \pm 0.4$ \\
\hline VS9 & $0-15$ & $0.84 \pm 0.1$ & $1.6 \pm 0.1$ & $1.2 \pm 0.4$ \\
\hline \multicolumn{5}{|c|}{ Biased samplesf } \\
\hline VB1 & $0-15$ & $1.2 \pm 0.2$ & $4.0 \pm 0.3$ & $2.6 \pm 0.5$ \\
\hline VB2 & $0-15$ & $1.2 \pm 0.1$ & $4.9 \pm 0.2$ & $2.6 \pm 0.5$ \\
\hline VB3 & $0-15$ & $0.99 \pm 0.1$ & $2.3 \pm 0.1$ & $1.1 \pm 0.2$ \\
\hline VB4s & $0-15$ & $2.3 \pm 0.2$ & $20 \pm 0.6$ & $7.3 \pm 0.8$ \\
\hline VB5g & $0-15$ & $1.8 \pm 0.1$ & $11 \pm 0.2$ & $10 \pm 1.0$ \\
\hline VB6A & $0-15$ & $0.96 \pm 0.1$ & $2.4 \pm 0.2$ & $2.0 \pm 0.4$ \\
\hline VB6B & $15-30$ & $1.3 \pm 0.1$ & $4.7 \pm 0.2$ & $3.5 \pm 0.5$ \\
\hline
\end{tabular}

aLocations of soil samples are shown on Fig. 2. Radionuclide concentrations are gross values; background concentrations have not been subtracted.

$b$ Indicated counting error is at the $95 \%$ confidence level $( \pm 2 \sigma)$.

c Systematic samples are taken at locations irrespective of gamma exposure rates.

$d$ Sample taken $\sim 2.5 \mathrm{ft}$ below surface of concrete floor of basement.

eVS2 samples taken from surface to $\sim 2.5-3 \mathrm{ft}$ below surface of concrete floor of basement.

$f$ Biased samples are taken from areas with elevated gamma exposure rates.

sSamples VB4 and VB5 were bounded by samples VS5-VS8. 
ORNL/RASA-96/3

\section{INTERNAL DISTRIBUTION}

\author{
1. K. J. Brown \\ 2. R. F. Carrier \\ 3. R. D. Foley \\ 4-5. C. A. Johnson \\ 6. M. E. Murray \\ 7. P. T. Owen \\ 8-10. R. E. Rodriguez
}

\author{
11-16. MAD Records Center \\ 17. R. E. Swaja \\ 18. M. S. Uziel \\ 19. J. K. Williams \\ 20. Central Research Library \\ 21. Laboratory Records-RC \\ 22. ORNL Technical Library, Y-12
}

\section{EXTERNAL DISTRIBUTION}

23. W. L. Beck, Oak Ridge Associated Universities, E/ESD, 1299 Bethal Valley Rd., Oak Ridge, TN 37831

24. S. M. Cange, Site Manager, Former Sites Restoration Division, Oak Ridge Operations Office, U. S. Department of Energy, P.O. Box 2001, Oak Ridge, TN 37831-8723

25. James J. Fiore, Director, Office of Eastern Area Programs, Office of Environmental Restoration, EM-24, U.S. Department of Energy, 19901 Germantown Rd., Germantown, MD 20874-1290

26. Albert Johnson, Program Manager, Formerly Utilized Sites Remedial Action Program, EM-421, U.S. Department of Energy, Cloverleaf Building, 19901 Germantown Rd, Germantown, MD 20874-1290

27. FUSRAP Document Center, Science Applications International Corporation, P.O. Box 2501, 301 Laboratory Road, Oak Ridge, TN 37831

28. S. K Oldham, Former Sites Restoration Division, Oak Ridge Field Office, U.S. Department of Energy, P.O. Box 2001, Oak Ridge, TN 37831-8723

29. L. K. Price, Director, Former Sites Restoration Division, Oak Ridge Field Office, U.S. Department of Energy, P.O. Box 2001, Oak Ridge, TN 37831-8723

30. Jack Russell, Booz-Allen \& Hamilton, Inc., 12850 Middlebrook Road, Suite 210, Germantown, MD 20874

31. A. G. Toddings, FUSRAP Project Administrator, Bechtel National, Inc., FUSRAP Department, Oak Ridge Corporate Center, 151 Lafayette Drive, P.O. Box 350 , Oak Ridge, TN 37831-0350

32-36. W. Alexander Williams, Designation and Certification Manager, Division of OffSite Programs, Office of Eastern Area Programs, Office of Environmental Restoration, EM-421, U.S. Department of Energy, 19901 Germantown Rd., Germantown, MD 20874-1290

37-38. Office of Scientific and Technical Information, U.S. Department of Energy, P.O. Box 62, Oak Ridge, TN 37831 